\title{
Unstable Variant of NADH Methemoglobin Reductase in Puerto Ricans with Hereditary Methemoglobinemia
}

\author{
Joel M. Schwartz, Phinip S. Paress, Jonathan M. Ross, \\ Frank DiPillo, and Rafael Rizek \\ From the Departments of Medicine at the State University of New York \\ Downstate Medical Center, Coney Island Hospital affliated with Maimonides \\ Medical Center, and Long Island College Hospital, Brooklyn, New York; and \\ the Department of Medicine, Municipal Hospital, San Juan, Puerto Rico
}

\begin{abstract}
A в S T RAC T The electrophoretic mobility of erythrocyte NADH methemoglobin reductase in five hereditary methemoglobinemia patients from three Puerto Rican kindreds was $118 \%$ of normal at $\mathrm{pH}$ 8.6. The methemoglobin ferrocyanide reductase activity of the enzyme in erythrocyte hemolysates was $3.2-6.4 \%$ of normal. Electrophoresis of hemolysates prepared from the blood of patients from two different families at six $\mathrm{pH}$ values between 4.6 and 9.3 did not differentiate between the variant enzymes. Examination of the deficient enzymes extracted from the erythrocytes of one patient from each kindred revealed altered affinity for $\mathrm{NADH}$ and dichloroindophenol dye and decreased thermal stability. The quantitative similarity of the abnormal findings, together with the Puerto Rican origin of the kindreds, suggested that the cyanotic patients possessed the same abnormal enzyme and were thus homozygous for the same rare mutant gene. Consanguinity of the kindreds could not be established.
\end{abstract}

The rates of decline of the normal and variant NADH methemoglobin reductase enzymes in vivo were measured in erythrocyte fractions of increasing cell age. The rate of decline of the variant enzyme was increased 20 -fold by comparison with the normal enzyme. The methemoglobin percentage in erythrocyte fractions of increasing cell age correlated inversely with the activity of the variant. The variant enzyme averaged $37 \%$ of normal mean activity in young cells and $1 \%$ in old cells. The normal enzyme, on the other hand, lost only one-sixth of its activity as the cells aged, and the methemoglobin

This work was presented in part at the Symposium on Red Blood Cell Structure and Metabolism in Jerusalem, Israel, August, 1969 (1) and in part in abstract form (2).

Received for publication 19 July 1971 and in revised form 13 January 1972. content in old normal cells did not rise. These observations support the hypothesis that the deficient activity and the heterogeneous pattern of methemoglobin accumulation in vivo arise principally from the accelerated inactivation of variant NADH methemoglobin reductase during the life-span of the red blood cell.

\section{INTRODUCTION}

Inherited methemoglobinemia arises either from structural alterations in the heme pocket of globin peptide chains which impede normal reduction of ferric heme (3), or as a result of marked deficiency of an NADHdependent methemoglobin-reducing enzyme (4). The hemoglobinopathic forms of methemoglobinemia, accounting for the hemoglobin $M$ diseases, are transmitted as autosomal dominant traits. Inheritance of the metabolic form of methemoglobinemia is typically recessive: parents and children of affected individuals have intermediate activity of NADH methemoglobin reductase but are not cyanotic (5). Deficient erythrocyte NADH methemoglobin reductase has been documented in at least 100 patients from 55 families in many parts of the world (4). The abnormal electrophoretic mobility of the residual methemoglobin reductase present in the red cells of some affected individuals (6-9) suggests heterogeneity of this enzymatic defect. This communication will describe certain physical and functional properties of erythrocyte NADH methemoglobin reductase in three hereditary methemoglobinemia families of Puerto Rican origin. The findings will be discussed in terms of their relevance to the function of the enzymes in vivo and to the cellular distribution of methemoglobin. 


\section{METHODS}

Reagents. Sodium salt of 2,6-dichloroindophenol (DCIP)1 was purchased from Eastman Organic Chemicals Div. (Eastman Kodak Co., Rochester, N. Y.) ; NADPH, sodium aspartate, and malate dehydrogenase from Boehringer Mannheim Corp. (New York); disodium EDTA, NADH, deamino NADH, [3-(4,5-dimethylthiazolyl-1,2)-2,5-diphenyltetrazolium bromide] (MTT), Tris, oxidized glutathione (GSSG), glucose-6-phosphate, and alpha ketoglutarate from Sigma Chemical Co. (St. Louis, Mo.); and crystalline saltfree bovine serum albumin from Armour Pharmaceutical Co. (Kankakee, Ill.). Mixtures of phthalate esters of predetermined specific gravity were obtained from Miles-Yeda, Rehovot, Israel; and diethylaminoethyl Sephadex (A50) and Sephadex G 100 from Pharmacia Fine Chemicals, Inc., Piscataway, N. J.

Subjects studied. The diagnosis of hereditary methemoglobinemia in the five women who were examined in this study was based on a history of cyanosis dating from birth, elevated blood methemoglobin level, and markedly reduced activity of erythrocyte NADH methemoglobin reductase. The cyanosis in each case disappeared temporarily after the intravenous injection of methylene blue. The women were from 14 to $48 \mathrm{yr}$ old, and none was mentally retarded. They were members of three apparently unrelated kindreds of Puerto Rican origin and included two sibling pairs: GT and NR (family T), AuC and AC (family C), and GR (family R). Neither their parents, their children, nor their grandchildren were cyanotic. There was no blood relatedness between the subjects' parents in any of the families.

100 healthy unrelated Puerto Rican adults, 1 Italian subject heterozygous for normal and variant NADH methemoglobin reductase, and 1 subject deficient in erythrocyte $\mathrm{NADPH}$ methemoglobin reductase were also examined.

Collection of blood samples. Freshly drawn venous blood was collected into heparin and immediately chilled, and was used for the fractionation of erythrocytes according to their density. The fractionation process was begun within $1 \mathrm{hr}$ of phlebotomy except for an $18 \mathrm{hr}$ delay in the case of patient AuC. Blood for purposes other than fractionation was collected into $0.2 \mathrm{vol}$ of acid-citrate-dextrose solution (NIH formula A).

Assay and kinetic analysis of NADH methemoglobin reductase. Two methods were used for the determination of NADH methemoglobin reductase in erythrocyte hemolysates: the DCIP dye reduction method (diaphorase method) of Scott (5), and the methemoglobin ferrocyanide reductase method of Hegesh, Calmanovici, and Avron (10). A modification of the diaphorase method was employed for kinetic analysis and heat stability studies of NADH methemoglobin reductase in partially purified enzyme extracts. The modified assay and the procedures used to measure the halfmaximal velocity constants $\left(K_{m}\right)$ for NADH and DCIP dye and the thermal stability of the enzyme have been described (1). The spectrophotometric reactions of NADH methemoglobin reductase and of the other enzymes reported in this paper were performed at $25^{\circ} \mathrm{C}$ in quartz cuvettes with $1 \mathrm{~cm}$ light path, and were measured with a Gilford model 220 spectrophotometer (Gilford Instrument Laboratories, Inc., Oberlin, Ohio) linked to a multiple sample absorbance recorder.

Partial purification of NADH methemoglobin reductase. $\mathrm{NADH}$ methemoglobin reductase was partially purified by

\footnotetext{
${ }^{1}$ Abbreviations used in this paper: DCIP, 2,6-dichloroindophenol; $K_{m}$, half-maximal velocity constant.
}

diethylaminoethyl Sephadex chromatography as previously described (1). The extraction produced 50 - to 120 -fold concentration of normal enzyme, measured as diaphorase per milligram protein, with $50-90 \%$ yield. The preparations were free of hemoglobin and of small molecules capable of directly reducing DCIP dye. The partially purified enzymes normally maintained full activity when stored at $4^{\circ} \mathrm{C}$ for at least 5 days. Nevertheless, variant and normal NADH methemoglobin reductase enzymes were characterized immediately after purification.

In vivo lability of $N A D H$ methemoglobin reductase. 80 $125-\mathrm{ml}$ samples of blood were subjected to density separation by differential flotation on mixtures of phthalate esters of known specific gravity (11). Portions of whole blood measuring $2.25 \mathrm{ml}$ mixed with $0.75 \mathrm{ml}$ of phthalate esters in $10 \times 76-\mathrm{mm}$ siliconized glass tubes were centrifuged in a swinging bucket rotor for $30 \mathrm{~min}$ at $12,000 \mathrm{~g}$ and $25^{\circ} \mathrm{C}$. The lightest layer of cells was usually removed from above fluid of 1.090 specific gravity, and the heaviest layer of cells was removed from below fluid of 1.114 specific gravity. In some blood samples, separation into fractions of red cells of intermediate densities was also performed. The fraction of lightest cells was recentrifuged and the contaminating white cells and platelets were separated above a fluid of 1.062 specific gravity. The red cell fractions and a sample of unfractionated red blood cells were washed with $0.15 \mathrm{M}$ potassium chloride until the supernate was clear. After the removal of portions for the measurement of methemoglobin, hemolysates were prepared (12) from the unfractionated red cells and from each of the density fractions, and the activities of $\mathrm{NADH}$ methemoglobin reductase, glutamic-oxalacetic transaminase, and glucose-6-phosphate dehydrogenase were determined. The activity of NADH methemoglobin reductase in each hemolysate was plotted on logarithmic paper against the corresponding activity of glutamic-oxalacetic transaminase or glucose-6-phosphate dehydrogenase. The slopes were calculated by the least-square method, and they were taken as an index of the NADH methemoglobin reductase enzyme's lability during the life-span of the red blood cell. Electrophoresis. Hemolysates and partially purified enzyme preparations were electrophoresed in starch gel, and stained for NADH methemoglobin reductase, NADPH methemoglobin reductase, and GSSG reductase according to the tetrazolium methods of Kaplan and Beutler $(6,13)$. The electrode chamber buffer system generally employed was $0.13 \mathrm{M}$ Tris-0.07 $\mathrm{m}$ boric acid-2.3 mM EDTA $\mathrm{pH}$ 8.6. The gel was prepared with the same buffer diluted 1:10 and with electrostarch (Otto Hiller, P. O. Box 1294, Madison, Wis.) in a concentration of $10 \mathrm{~g} / 100 \mathrm{ml}$. Destromatized freeze-thaw hemolysates prepared from $50 \%$ suspensions of washed erythrocytes were added in $150 \mu \mathrm{l}$ volume to each slot of a five-slot gel. For the electrophoresis of enzyme extracts, $40-\mu 1$ samples were added to each slot of a 10-slot gel. Electrophoresis was performed at $4^{\circ} \mathrm{C}$ in the horizontal position utilizing a constant current of $10 \mathrm{ma}$ for $16 \mathrm{hr}$ or $30 \mathrm{ma}$ for $4 \mathrm{hr}$. The sliced gels were stained in the dark for $3 \mathrm{hr}$ with freshly made reaction mixtures. The background stain and the hemoglobin were removed by washing the gel in cold deionized water for 1-3 days.

The mobility of variant $\mathrm{NADH}$ methemoglobin reductase bands was determined at additional $\mathrm{pH}$ values between 4.5 and 9.3. The electrode chamber buffer systems were $0.1 \mathrm{M}$ Tris-4.5 mM EDTA pH 9.3; 0.093 м disodium phosphate$0.007 \mathrm{M}$ sodium phosphate-8 mM EDTA $\mathrm{pH} 7.5 ; 0.064 \mathrm{M}$ disodium phosphate- $0.036 \mathrm{~m}$ sodium phosphate- $5 \mathrm{~mm}$ EDTA $\mathrm{pH} 7.0 ; 0.022 \mathrm{M}$ citric acid- $0.056 \mathrm{M}$ disodium phosphate-3 
mм EDTA $\mathrm{pH} 5.6$; and $0.05 \mathrm{~m}$ acetic acid- $0.05 \mathrm{M}$ sodium acetate-3 mM EDTA $\mathrm{pH}$ 4.5. The relative electrophoretic mobility of variant bands was expressed as a percentage of the migration of normal NADH methemoglobin reductase on the same starch gel.

Molecular weight determination of NADH methemoglobin reductase. $1 \mathrm{ml}$ of clear hemolysate $(150 \mathrm{mg}$ hemoglobin/ $\mathrm{ml}$ ) or of partially purified enzyme extract was dialyzed for 2 hr against 2 liters of $0.005 \mathrm{~m}$ potassium phosphate buffer $\mathrm{pH}$ 6.45 containing $0.1 \mathrm{~mm}$ EDTA and $0.1 \mathrm{~m}$ potassium chloride. The dialyzed sample was applied to a $2.5 \times 34.0 \mathrm{~cm}$ column of Sephadex G 100 previously equilibrated with the same buffer, and was eluted with buffer flowing at a rate of $22 \mathrm{ml} / \mathrm{hr}$. 1-ml fractions were collected and assayed for $\mathrm{NADH}$ methemoglobin reductase, adjusting the assay mix when hemoglobin contaminated the eluate (after the application of hemolysate) so that the final concentration of methemoglobin ferrocyanide was kept constant. The enzyme's distribution coefficient was calculated (14), and the molecular weight determined by reference to the selectivity curve constructed from the elution patterns of aldolase, ovalbumin, chymotrypsinogen $\mathrm{A}$ and ribonuclease $\mathrm{A}$. The elution peak of NADH methemoglobin reductase was concentrated by dialysis under reduced pressure, and was electrophoresed in starch gel.

The methemoglobin content of washed red blood cells was quantified spectrophotometrically by the procedure of Evelyn and Malloy (15). Standard techniques were employed for the spectrophotometric determination of hemoglobin (16), GSSG reductase (17), glucose-6-phosphate dehydrogenase (12), and glutamic-oxalacetic transaminase (18) in red blood cell hemolysates. Student's $t$ test was employed for the statistical analysis of paired observations (19).

\section{RESULTS}

The NADH methemoglobin reductase of erythrocyte hemolysate normally migrates in starch gel at $\mathrm{pH} 8.6$ as a single band anodal to the position of hemoglobin $A_{2}$.
The normal band was absent from the hemolysates and partially purified enzyme extracts of all five hereditary methemoglobinemia patients. Instead, a faint NADH methemoglobin reductase band was observed with mobility $117-118 \%$ of normal (Table I and Fig. 1). Hemolysates prepared from the blood of patients from two different families (GR and GT) were electrophoresed at five additional $\mathrm{pH}$ values between 4.6 and 9.3. The mobility of the variant bands in the respective hemolysates was identical: $93 \%$ of normal at $\mathrm{pH} 4.7,250 \%$ at $\mathrm{pH} 5.6,143 \%$ at $\mathrm{pH} 7.0,124 \%$ at $\mathrm{pH} 7.5$, and $117 \%$ at $\mathrm{pH}$ 9.3. The migration of normal and variant enzyme bands was toward the cathode at $\mathrm{pH} 4.7$ and toward the anode at $\mathrm{pH} 5.6$ and greater. The staining of the variant bands was more intense after electrophoresis at $\mathrm{pH} 5.6$, 7.0 , and 7.5 than at the more acid and alkaline values which were tested.

The activity range of $\mathrm{NADH}$ methemoglobin reductase in the erythrocyte hemolysates of the five methemoglobinemia patients was $3.2-6.4 \%$ of the normal mean (Table I). Kinetic analysis of the partially purified $\mathrm{NADH}$ methemoglobin reductase enzymes extracted from the blood of one hereditary methemoglobinemia patient in each of the families revealed higher than normal $K_{m}$ NADH and lower than normal $K_{m}$ DCIP (Table II). There was no overlap of the data observed for the variant and normal enzymes. The thermal stability of the variant $\mathrm{NADH}$ methemoglobin reductase enzymes was moderately reduced (Fig. 2).

No significant differences were observed in the enzyme activities or in the methemoglobin content of unfractionated erythrocytes after three passages through the phthalate esters ( $t$ tests, $P>0.1$ ). The method of

TABLE I

Hematologic Data, and Activity and Electrophoretic Mobility of Methemoglobin and Glutathione Reductases in Hemolysates of Five Methemoglobinemia Patients

\begin{tabular}{|c|c|c|c|c|c|c|c|c|}
\hline Subjects & Age & Hemoglobin & $\begin{array}{c}\text { Methemo- } \\
\text { globin* }\end{array}$ & $\begin{array}{c}\text { NADH } \\
\text { methgb } \\
\text { reductase } \\
\text { activity } \ddagger\end{array}$ & $\begin{array}{l}\text { GSSG } \\
\text { reductase } \\
\text { activity }\end{array}$ & $\begin{array}{l}\text { NADH } \\
\text { methgb } \\
\text { reductase } \\
\text { mobility } \$\end{array}$ & $\begin{array}{l}\text { NADPH } \\
\text { methgb } \\
\text { reductase } \\
\text { mobility } \|\end{array}$ & $\begin{array}{c}\text { GSSG } \\
\text { reductase } \\
\text { mobilityll }\end{array}$ \\
\hline & $y r$ & $\mathrm{~g} / 100 \mathrm{ml}$ & $\%$ & $\begin{array}{c}\mu m o l e s / \min \\
\text { per } g h g b\end{array}$ & $\begin{array}{c}\mu m o l e s / \min \\
\text { per } g \text { hgb }\end{array}$ & & & \\
\hline GR & 14 & 13.4 & 21.4 & $\begin{array}{lll}0.26, & 0.12, & 0.10\end{array}$ & 3.32 & 118 & Normal & Normal \\
\hline GT & 25 & 13.9 & 13.3 & $\begin{array}{lll}0.20, & 0.12, & 0.08\end{array}$ & 3.45 & 118 & Normal & Fast \\
\hline NR & 23 & 14.0 & 11.1 & $\begin{array}{lll}0.17, & 0.12, & 0.07\end{array}$ & 2.70 & 118 & Normal & Normal \\
\hline $\mathrm{AuC}$ & 48 & 17.0 & 13.4 & $\begin{array}{lll}0.10, & 0.07, & 0.06\end{array}$ & - & 117 & Normal & Normal \\
\hline $\mathrm{AC}$ & 46 & 15.7 & 12.9 & 0.09 & - & 117 & Normal & Normal \\
\hline Normal values & & & $\begin{array}{c}0-1.5 \\
n=22\end{array}$ & $\begin{array}{c}2.51 \pm 0.539 \\
\mathrm{n}=22\end{array}$ & $\begin{array}{c}3.94 \pm 0.659 \\
n=26\end{array}$ & $\mathrm{n}=100$ (00** & $\underset{\mathrm{n}=100^{* *}}{\text { Normal }}$ & $\begin{array}{l}99 \text { Normal, } 1 \text { Fast } \\
\mathrm{n}=100^{* *}\end{array}$ \\
\hline
\end{tabular}

* Mean values.

‡ NADH methemoglobin reductase determined by methemoglobin ferrocyanide method (Hegesh). Where more than one value is given, determination were performed on different blood samples.

$\$$ Per cent normal mobility.

|| Mobilities of normal NADPH methemoglobin reductase and of normal and fast GSSG reductase are respectively 260,105 and $133 \%$ normal NADH methemoglobin reductase.

I Mean \pm SD.

** Normal Puerto Rican adults. 
fractionation with phthalate esters was, therefore, considered adequate for studies of enzyme lability and methemoglobin accumulation. Comparisons of normal and methemoglobinemia erythrocyte fractions separated according to their density are presented in Table III. Age separation was indicated by the findings of a 5.2-fold difference in the activity of glutamic-oxalacetic transaminase between lightest ("young") and heaviest ("old") fractions and a 2.2-fold difference in the activity of glucose-6-phosphate dehydrogenase.

The older cells of normal subjects contained $16 \%$ less $\mathrm{NADH}$ methemoglobin reductase (measured as methemoglobin ferrocyanide reductase) on the average than the young cells $(P<0.001)$, but they did not differ in their methemoglobin content $(P>0.4)$.

The activity of $\mathrm{NADH}$ methemoglobin reductase in the younger cells of four patients with hereditary methemoglobinemia was increased 8.4 -fold by comparison with the unfractionated erythrocytes, and averaged $37 \%$ of the normal mean activity. In contrast to the mild reduction in activity observed during the aging of normal cells, the activity of the enzyme was nearly exhausted in the old methemoglobinemia cells. Further, the

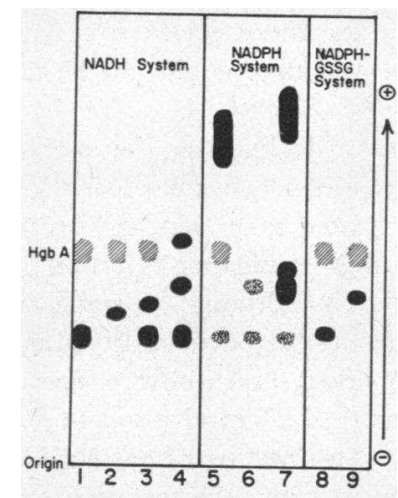

FIgure 1 Scale drawing of the electrophoretic mobilities in starch gel at $\mathrm{pH}$ 8.6. NADH Methgb- $\mathrm{R}$ is represented in the left panel. Position 1, normal hemolysate. Position 2, hemolysate of Puerto Rican homozygote. Position 3, hemolysate of "Boston Fast" heterozygote. Position 4, normal enzyme extract stored at $4^{\circ} \mathrm{C}$ : note fast bands which have formed in vitro accompanied by less intense staining of primary band. NADPH Methgb-R and cross activity (stippled) of concentrated NADH Methgb-R are represented in center panel. Position 5, normal hemolysate. Position 6, enzyme extract of patient with homozygous deficiency of NADPH Methgb-R; note complete absence of the normal NADPH Methgb-R bands. Position 7, normal enzyme extract; note the primary NADPH Methgb-R zone spread more anodally than in hemolysate, and a broad new zone cathodal to hemoglobin A. GSSG-R is represented in the right panel. Simultaneously stained NADPH Methgb-R band is omitted from the drawing. Position 8 , normal hemolysate. Position 9, hemolysate of patient GR; note fast GSSG-R variant and complete absence of the normal band. Methgb- $R$ is methemoglobin reductase, GSSG-R is glutathione reductase.
TABLE II

Determinations of $K m$ for $N A D H$ and DCIP

\begin{tabular}{|c|c|c|c|c|c|c|}
\hline & \multirow{2}{*}{$\begin{array}{l}\text { Number } \\
\text { of } \\
\text { subjects }\end{array}$} & \multicolumn{2}{|c|}{$K_{m} \mathrm{NADH}$} & \multirow{2}{*}{$\begin{array}{l}\text { Number } \\
\text { of } \\
\text { subjects }\end{array}$} & \multicolumn{2}{|c|}{$K_{m}$ DCIP } \\
\hline & & Mean & Range & & Mean & Range \\
\hline & & & $\mu \mathbf{M}$ & & & $\boldsymbol{\mu} \mathbf{M}$ \\
\hline Normal & $5(9)$ & 1.2 & $0.5-2.2$ & $5(8)$ & 154 & 124-191 \\
\hline GR & $1(3)$ & 4.1 & $3.6-4.6$ & $1(3)$ & 28 & $23-34$ \\
\hline GT & $1(2)$ & 5.6 & $5.3-5.9$ & $1(2)$ & 55 & $36-75$ \\
\hline $\mathrm{AuC}$ & $1(1)$ & 7.8 & - & $1(1)$ & 22 & - \\
\hline
\end{tabular}

Figures within the parentheses indicate the number of enzyme preparations tested.

$K_{m}$ values for $\mathrm{NADH}$ were calculated from the regression of S/V against $\mathrm{S}$, and for DCIP from the regression of $\mathrm{V}$ against $\mathrm{V} / \mathrm{S} . \mathrm{V}$ is initial velocity and $\mathrm{S}$ is substrate concentration.

methemoglobin percentage in the blood of the patients with hereditary methemoglobinemia was markedly increased in the old $(28 \%)$ as compared with the young $(8 \%)$ red blood cells (Table III).

The methemoglobin level in the youngest cells of the patients with hereditary methemoglobinemia was elevated above normal even when their enzyme activity approached the normal range (Fig. 3). The methemoglobin level in erythrocyte fractions of increasing density increased progressively as the enzyme activity declined, and increased precipitously in the very oldest fractions of GR, NR, and GT (GT not shown in Fig. 3) with activity below $1 \%$ of normal. The marked increase in the methemoglobin of fractions with activity below $1 \%$ of normal was obscured in $\mathrm{AuC}$ in whom fractionation of erythrocytes was delayed for $18 \mathrm{hr}$ and suboptimal age separation achieved: glutamic-oxalacetic transaminase
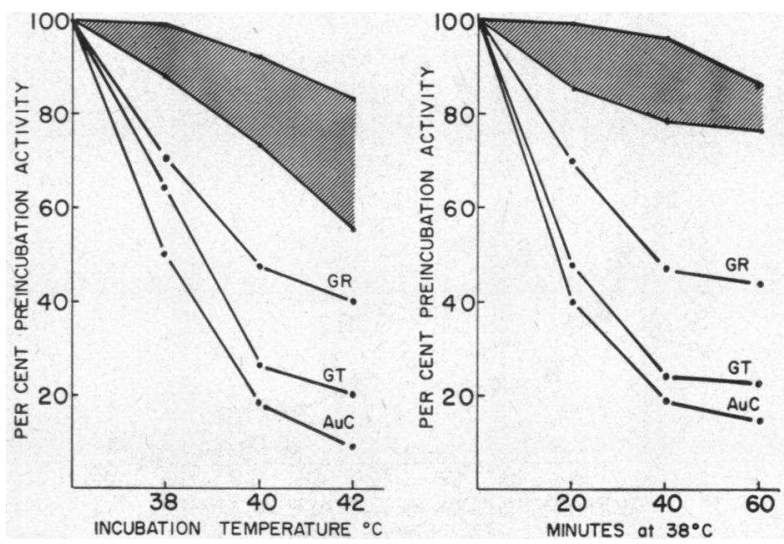

Figure 2 Activity of $\mathrm{NADH}$ methemoglobin reductase in freshly prepared enzyme extracts after $20 \mathrm{~min}$ incubation at 38,40 , and $42^{\circ} \mathrm{C}$ (left panel) and after 20,40 , and $60 \mathrm{~min}$ incubation at $38^{\circ} \mathrm{C}$ (right panel). Paired normal and variant enzyme extracts equal in activity and protein concentration are simultaneously tested. Shaded areas are range in six normal subjects. Curves for GR and GT are typical of several experiments performed for each. 
TABLE III

Enzymatic Activities and Methemoglobin Content of Erythrocytes Separated According to their Density

\begin{tabular}{|c|c|c|c|c|c|c|c|c|}
\hline & \multicolumn{2}{|c|}{$\begin{array}{l}\text { Glutamic-oxalacetic } \\
\text { transaminase }\end{array}$} & \multicolumn{2}{|c|}{$\begin{array}{l}\text { Glucose-6-phosphate } \\
\text { dehydrogenase }\end{array}$} & \multicolumn{2}{|c|}{$\begin{array}{l}\text { NADH methemoglobin } \\
\text { reductase* }\end{array}$} & \multicolumn{2}{|c|}{ Methemoglobin } \\
\hline & $\begin{array}{l}\text { Patients } \\
\mathrm{n}=4\end{array}$ & $\begin{array}{l}\text { Control } \\
\mathrm{n}=5\end{array}$ & $\begin{array}{l}\text { Patients } \\
\mathrm{n}=4\end{array}$ & $\begin{array}{l}\text { Control } \\
\mathbf{n}=5\end{array}$ & $\begin{array}{l}\text { Patients } \\
\mathrm{n}=4\end{array}$ & $\begin{array}{l}\text { Control } \\
n=8\end{array}$ & $\begin{array}{c}\text { Patients } \\
\mathrm{n}=4\end{array}$ & $\begin{array}{l}\text { Control } \\
n=6\end{array}$ \\
\hline $1-3 \%$ youngest $\mathrm{RBC}$ & $5.2(4.0-7.7)$ & $5.8(3.8-8.9)$ & $8.9(7.5-10.9)$ & $10.2(6.7-16.6)$ & $0.92(0.46-1.62)$ & $2.89(1.72-3.90)$ & \multicolumn{2}{|c|}{$\%$} \\
\hline $1-3 \%$ oldest $\mathrm{RBC}$ & $1.0(0.6-2.0)$ & $1.1(0.7-1.5)$ & $4.1(3.3-5.4)$ & $4.7(3.6-6.1)$ & $0.02(0.00-0.07)$ & $2.44(1.38-3.36)$ & $27.5(16.1-41.9)$ & $1.5(0.7-2.4)$ \\
\hline Total RBC $\ddagger$ & $2.1(1.5-2.5)$ & $2.6(2.2-2.9)$ & $6.3(6.0-6.9)$ & $7.1(5.7-9.8)$ & $0.11(0.08-0.17)$ & $2.65(1.63-3.51)$ & $15.5(11.4-21.0)$ & $0.9(0.8-1.3)$ \\
\hline Normal values & \multicolumn{2}{|c|}{$\begin{array}{l}2.7 \pm 0.6 \\
n=25\end{array}$} & \multicolumn{2}{|c|}{$\begin{array}{l}6.5 \pm 0.8 \\
n=24\end{array}$} & \multicolumn{2}{|c|}{$\begin{array}{c}2.51 \pm 0.53 \\
n=22\end{array}$} & \multicolumn{2}{|c|}{$\begin{array}{c}0-1.5 \\
\mathrm{n}=22\end{array}$} \\
\hline
\end{tabular}

Values are mean values, ranges indicated in parentheses.

Enzyme activities in micromoles substrate consumed/minute per gram hemoglobin.

* Determined by methemoglobin ferrocyanide method (Hegesh).

$\ddagger$ Unfractionated erythrocytes washed free of plasma and buffy coat.

$P<0.05$ for paired comparisons of young, unfractionated and old RBC in all categories except methemoglobin in controls.

in "old"/unfractionated cells of $\mathrm{AuC}=0.93$, of other subjects $=0.30-0.61$.

The average rate of loss of erythrocyte NADH methemoglobin reductase with increasing cell age was 0.13 in control blood and 2.32 in methemoglobinemia blood when methemoglobin reductase was plotted against glutamic-oxalacetic transaminase, and 0.22 in control blood and 4.59 in methemoglobinemia blood when methemoglobin reductase was plotted against glucose-6-phosphate dehydrogenase (Fig. 4). The decline in NADH methemoglobin reductase activity was thus 20 -fold faster in

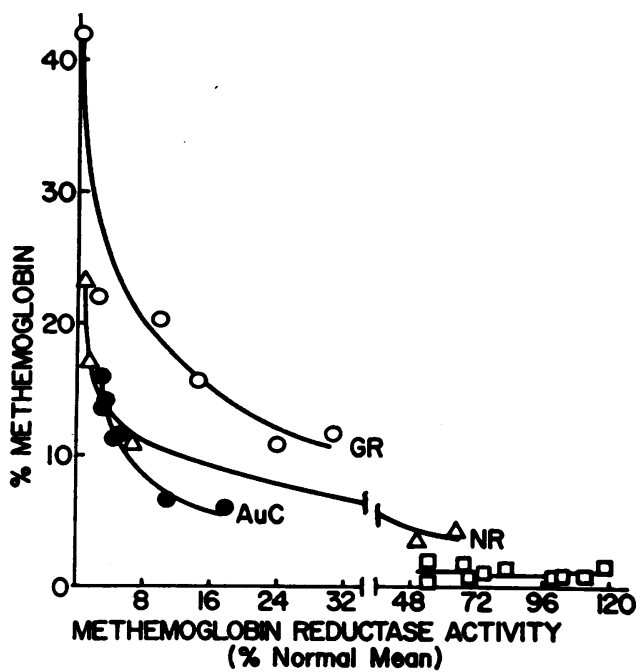

FIGURE 3 Activity of NADH methemoglobin reductase and proportion of methemoglobin in erythrocyte fractions separated according to their density. Activities of unfractionated erythrocytes of $\mathrm{GR}, \mathrm{NR}$, and $\mathrm{AuC}$ were $4.0,6.8$, and $4.0 \%$ normal, and the corresponding methemoglobin levels were $21.0,11.4$, and $12.6 \%$. Normal ( 2 sD) enzyme activity range is $58-143 \%$ of normal mean activity. $\square \square \square$, experiments in three normal subjects. hereditary methemoglobinemia erythrocytes than in control erythrocytes. The heaviest two erythrocyte fractions of patient GR contained $0.00 \mathrm{U}$ of NADH methemoglobin reductase, 0.6 and $0.5 \mathrm{U}$ of glutamic-oxalacetic transaminase, and 3.7 and $3.3 \mathrm{U}$ of glucose-6-phosphate dehydrogenase. Because of the logarithmic nature of the plots, the values for these erythrocyte fractions are not shown in Fig. 4 and they could not be used for computation of the slopes.

The accelerated decline in the activity of variant NADH methemoglobin reductase with increasing cell age was demonstrated in patient GT by the use of both the diaphorase and methemoglobin ferrocyanide assay systems (Table IV). Although enzyme activity was not detectable in oldest erythrocytes assayed by either method (or in unfractionated erythrocytes assayed by the diaphorase method), the activity of the enzyme in the youngest erythrocyte fraction of patient GT equaled $21 \%$ of the normal mean when the terminal electron acceptor was DCIP dye and $34 \%$ of the normal mean when it was methemoglobin ferrocyanide. Similarly, the age-dependent decline in the activity of normal NADH methemoglobin reductase in two control subjects demonstrated with the methemoglobin ferrocyanide test system was accompanied by comparable decline in the diaphorase activity (Table IV).

The molecular weight of normal NADH methemoglobin reductase in freshly prepared erythrocyte hemolysates and enzyme extracts, determined from the position of the enzyme's elution from a calibrated Sephadex G 100 column, was 31,000 . This value agrees closely with the estimate by Hegesh, Calmanovici, Lupo, and Bochkowsky (20). There was no change in the elution profile or in the activity of the normal enzyme after storage for 8 days at $4^{\circ} \mathrm{C}$ despite coincident changes in the electrophoretic pattern (Fig. 1). The NADH methemoglobin 


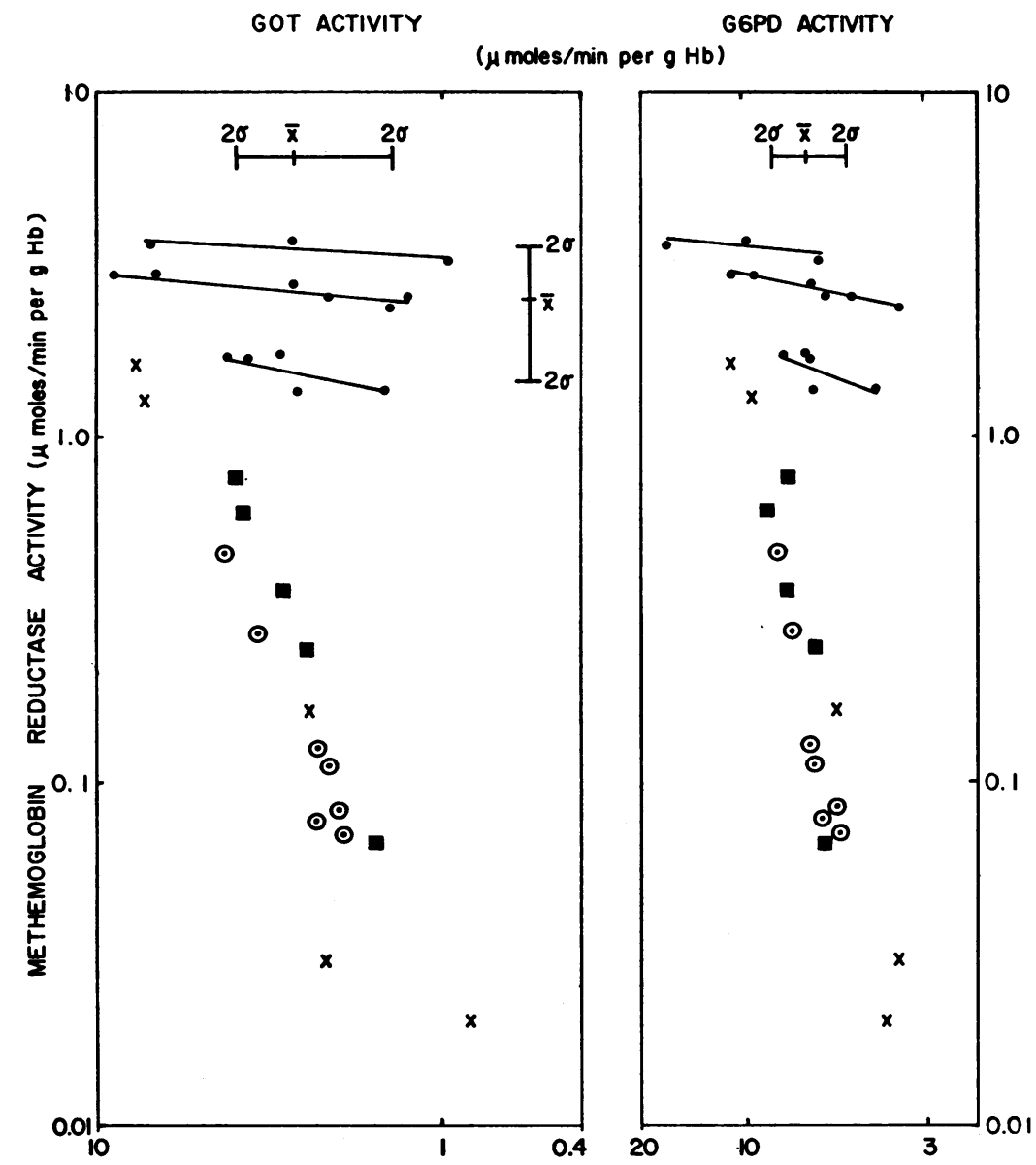

FIgURE 4 Activity of NADH methemoglobin reductase expressed as a function of the activity of glutamic-oxalacetic transaminase (GOT) and glucose-6phosphate dehydrogenase (G6PD). Symbols: $\bullet$, normal subjects; $\times$, patient NR; $\odot$, patient AuC; $\square$, patient GR. Logarithmic scale used for vertical and horizontal axes.

reductase extracted from the blood of a subject heterozygous for the normal enzyme and a variant with nearly normal staining intensity ("Boston Fast" [9] variant, Fig. 1) eluted as a single peak at the normal position.

No electrophoretic variants of erythrocyte NADH methemoglobin reductase were detected in 100 normal Puerto Rican subjects (Table I). A rapidly migrating variant of erythrocyte GSSG reductase was present in one control subject and one methemoglobinemia patient (Table I and Fig. 1). A sharp formazan band observed to underlie the position of the major hemoglobin components $(A, F, G$, and $S)$ in all tested hemolysates, including those prepared from erythrocytes deficient in NADPH- or NADH methemoglobin reductase, was probably due to the direct reduction of DCIP by ferrous hemoglobin. The band was present when pyridine nucleotide was omitted from the staining mixture. The band was absent after electrophoresis of partially purified enzyme extracts free of hemoglobin.

\section{DISCUSSION}

The erythrocyte NADH methemoglobin reductase enzymes of the hereditary methemoglobinemia patients examined in this study are abnormal by virtue of more negative surface charge, altered affinity for the NADH and DCIP substrates, decreased thermal stability, and accelerated loss of activity during the life-span of the cell. The quantitative similarity of the abnormal findings in affected members of the three families, together with the Puerto Rican origin of the kindreds, suggests a common genetic mutation. Although each of the families originated from cities in the Northwest portion of Puerto Rico, we were not able to establish consanguinity. Heterogeneous distribution of methemoglobin has been 
TABLE IV

Comparison of Diaphorase and Methemoglobin Ferrocyanide Reductase Activities of NADH Methemoglobin Reductase in Young and Old Red Blood Cells

\begin{tabular}{|c|c|c|c|c|}
\hline Subject & Sample & $\begin{array}{l}\text { Glutamic- } \\
\text { oxalacetic } \\
\text { transaminase }\end{array}$ & $\begin{array}{l}\text { NADH } \\
\text { Methgb } \\
\text { ferrocyanide } \\
\text { reductase }\end{array}$ & $\begin{array}{c}\text { NADH } \\
\text { diaphorase* }\end{array}$ \\
\hline & & $\mu$ moles/min per $\mathrm{g} h \mathrm{hb}$ & $\mu$ moles $/$ min per $\mathrm{g} h g b$ & $\triangle O D \times 104 / \mathrm{min}$ per $3.0 \mathrm{mg} \mathrm{hgb}$ \\
\hline Patient GT & $\begin{array}{l}1-3 \% \text { youngest } \mathrm{RBC} \\
1-3 \% \text { oldest } \mathrm{RBC} \\
\text { Total RBC } \ddagger\end{array}$ & $\begin{array}{l}4.9 \\
0.8 \\
2.3\end{array}$ & $\begin{array}{l}0.85 \\
0.00 \\
0.08\end{array}$ & $\begin{array}{r}+12.9 \\
-14.0 \\
-5.1\end{array}$ \\
\hline Normal & $1-3 \%$ youngest $\mathrm{RBC}$ & $5.2(4.5) \S$ & $2.96(2.78)$ & $61.5(65.4)$ \\
\hline Control & $\begin{array}{l}1-3 \% \text { oldest RBC } \\
\text { Total RBC } \neq\end{array}$ & $\begin{array}{l}0.7(1.1) \\
2.2(2.3)\end{array}$ & $\begin{array}{ll}2.46 & (2.35) \\
2.52 & (2.45)\end{array}$ & $\begin{array}{l}49.3(51.9) \\
51.2(55.8)\end{array}$ \\
\hline
\end{tabular}

* NADH diaphorase mean \pm SD in 11 normal subjects $=62.3 \pm 13.2$.

$\ddagger$ Unfractionated erythrocytes washed free of plasma and buffy coat.

$\$$ Mean values for studies in two normal subjects indicated within parentheses.

observed in a patient with hereditary methemoglobinemia studied by Keitt, Smith, and Jandl (21). The authors could not correlate the increased level of methemoglobin in the older cells with loss of $\mathrm{NADH}$ methemoglobin reductase (measured as diaphorase), and they attributed it instead to critical decline in the activity of an ancillary methemoglobin-reducing pathway involving reduced glutathione (GSH) and the hexose monophosphate shunt. The levels of methemoglobin in the oldest and youngest cells of the Puerto Rican patients with hereditary methemoglobinemia are similar to those in the patient studied by Keitt et al. (21). Analysis of erythrocyte fractions of increasing density suggests, however, that the accumulation of methemoglobin is related to the declining activity of the variant NADH methemoglobin reductase, and possibly to its catalytic inefficiency.

The elevated methemoglobin level in erythrocyte fractions with normal and intermediate enzyme activity may result from uneven distribution of methemoglobin and of active enzyme in the sampled cells. Alternatively, this finding may mean that the in vivo function of the variant enzyme is abnormal due to changed conformationa view suggested by the altered substrate affinities-but it is not possible to be sure of this since a nonphysiological (diaphorase) test system was employed. The rapid decrease in NADH methemoglobin reductase is accompanied by progressive increase in methemoglobin, and the virtual loss of activity in the oldest cells is signaled by a precipitous rise in their methemoglobin content. The various methemoglobin levels found in erythrocyte fractions of patients with similarly low enzymatic activity (Fig. 3) may reflect differences in intracellular oxidant stresses and/or in the capacity of secondary mechanisms of methemoglobin reduction, such as GSH, ascorbic acid and perhaps NADPH methemoglobin reductase.

At least five different electrophoretic variants of erythrocyte NADH methemoglobin reductase associated with low activity and with methemoglobinemia are currently known (4). The in vivo deficiency of the enzymes might arise from retarded synthesis of the enzyme, inefficient catalytic function, increased lability or a combination of these factors. The degree of the methemoglobinemia and the cellular distribution of the methemoglobin will depend partly on which mechanisms operate and on the severity of the resulting defect.

The rate of synthesis of the variant NADH methemoglobin reductase in the Puerto Rican patients is unknown and the physiologic significance of the altered substrate affinities is uncertain. Nevertheless, the present studies support the hypothesis that the deficient activity and the heterogeneous pattern of methemoglobin accumulation arise principally from the accelerated inactivation of variant enzyme during the life-span of the red cell. The lability of the variant enzyme in the erythrocytes of Puerto Rican patients with hereditary methemoglobinemia is analogous to the in vivo lability of the A- and Mediterranean variants $(22,23)$ of glucose-6-phosphate dehydrogenase in patients susceptible to oxidant drug-induced hemolysis. The precise structural alterations which underlie increased in vivo lability of deficient glucose-6-phosphate dehydrogenase and $\mathrm{NADH}$ methemoglobin reductase enzymes are unknown. Inference by analogy with unstable hemoglobin molecules (24) suggests that substitution or deletion of one or more amino acids may have severely distorted the configuration of the enzyme molecule, disrupted normal contact between subunits, or interfered with the 
binding of a prosthetic group or coenzyme which confers stability on the molecule as a whole. ${ }^{2}$

Conflicting reports in the literature indicate stability (21) and lability (26) of normal NADH methemoglobin reductase as red blood cells age in vivo. The discrepant results may reflect varying degrees of success in separating erythrocytes into younger and older cell populations. Feig, Nathan, and Gerald (26) have observed accelerated age-dependent decline in the activity of variant $\mathrm{NADH}$ methemoglobin reductase present in the erythrocytes of an Italian subject with slightly elevated blood methemoglobin level.

\section{ACKNOWLEDGMENTS}

We wish to acknowledge the statistical analysis provided by Dr. Stuart Kahan of the Division of Computer Science, State University of New York Downstate Medical Center, supported in part by grant FR00291 from the U. S. Public Health Service. The authors are indebted to Mr. Martin D. Sass of the Veterans Administration Hospital, Brooklyn, N. Y., who made available blood of a patient deficient in erythrocyte NADPH methemoglobin reductase, and Doctors Ernst R. Jaffé and Henry Haberfeld who carefully reviewed the manuscript and offered helpful suggestions.

This work was supported by U. S. Public Health Service grant HE-13585 and General Research Support grant FR05497.

\section{REFERENCES}

1. Schwartz, J. M., J. M. Ross, P. S. Paress, K. Fagelman, and L. Fogel. 1971. Electrophoretic and kinetic characterization of a NADH-diaphorase variant in a methemoglobinemia subject. In Red Blood Cell Structure and Metabolism. B. Ramot, editor. Academic Press Inc., New York. 135.

2. Schwartz, J. M., P. S. Paress, J. M. Ross, K. Fagelman, F. W. DiPillo, and R. Rizek. 1970. A Puerto Rican variant of $\mathrm{NADH}$ methemoglobin reductase in hereditary methemoglobinemia. Clin. Res. 18: 346. (Abstr.)

3. Gerald, P. S., and M. L. Efron. 1961. Chemical studies of several varieties of hemoglobin M. Proc. Nat. Acad. Sci.U.S. A. $47: 1758$.

4. Jaffé, E. R., and H. S. Hsieh. 1971. DPNH-methemoglobin reductase deficiency and hereditary methemoglobinemia. Seminars Hematol. 8: 417.

5. Scott, E. M. 1960. The relation of diaphorase of human erythrocytes to inheritance of methemoglobinemia. $J$. Clin. Invest. 39 : 1176.

6. Kaplan, J. C., and E. Beutler. 1967. Electrophoresis of red cell NADH- and NADPH-diaphorases in normal subjects and patients with congenital methemoglobinemia. Biochem. Biophys. Res. Commun. 29: 605.

7. West, C. A., B. D. Gomperts, E. R. Huehns, I. Kessel, and J. R. Ashby. 1967. Demonstration of an enzyme

\footnotetext{
'Those enzymes which have been examined by X-ray crystallography have all been shown to be globular molecules with folding of their polypeptide chain(s) (25). They resemble hemoglobin in this respect and it is reasonable to suppose that the factors which affect the stability of their globular structures are similar.
}

variant in a case of congenital methaemoglobinaemia. Brit. Med. J. $4: 212$.

8. Bloom, G. E., and H. S. Zarkowski. 1969. Heterogeneity of the enzymatic defect in congenital methemoglobinemia. N. Engl. J. Med. 281 : 919.

9. Hsieh, H. S., and E. R. Jaffé. 1971. Electrophoretic and functional variants of NADH-methemoglobin reductase in hereditary methemoglobinemia. J. Clin. Invest. 50: 196.

10. Hegesh, E., N. Calmanovici, and M. Avron. 1968. New method for determining ferrihemoglobin reductase (NADH-methemoglobin reductase) in erythrocytes. $J$. Lab. Clin. Med. 72: 339.

11. Danon, D., and Y. Marikowsky. 1964. Determination of density distribution of red cell population. J. Lab. Clin. Med. 64 : 668.

12. Loder, P. B., and G. C. DeGruchy. 1965. Red-cell enzymes and coenzymes in non-spherocytic congenital haemolytic anaemias. Brit. J. Haematol. 11: 21.

13. Kaplan, J. C., and E. Beutler. 1968. Electrophoretic study of glutathione reductase in human erythrocytes and leucocytes. Nature (London). 217: 256.

14. Andrews, P. 1964. Estimation of the molecular weights of proteins by Sephadex gel-filtration. Biochem. J. 91: 222.

15. Evelyn, K. A., and H. T. Malloy. 1938. Microdetermination of oxyhemoglobin, methemoglobin and sulfhemoglobin in a single sample of blood. J. Biol. Chem. 126: 655.

16. Cartwright, G. E. 1968. Diagnostic Laboratory Hematology. Grune \& Stratton, Inc., New York. 4th edition. 76.

17. Gross, R. T., R. Bracci, N. Rudolph, E. Schroeder, and J. A. Kochen. 1967. Hydrogen peroxide toxicity and detoxification in the erythrocytes of newborn infants. Blood. 29: 481.

18. Steinberg, D., and B. H. Ostrow. 1955. Serum transaminase as a measure of myocardial necrosis. Proc. Soc. Exp. Biol. Med. 89: 31 .

19. Snedecor, G. W. 1956. Statistical Methods. Applied to Experiments in Agriculture and Biology. Iowa State University Press, Ames, Iowa. 5th edition. 35.

20. Hegesh, E., N. Calmanovici, M. Lupo, and R. Bochkowsky. 1971. The diaphorase bands of human erythrocytes. J. Lab. Clin. Med. $77: 859$.

21. Keitt, A. S., T. W. Smith, and J. H. Jandl. 1966. Redcell "pseudomosaicism" in congenital methemoglobinemia. N. Engl.J. Med. 275 : 399.

22. Yoshida, A., A. Stamatoyannopoulos, and A. G. Motulsky. 1967. Negro variant of glucose-6-phosphate dehydrogenase deficiency (A-) in man. Science (Washington). 155 : 97.

23. Piomelli, S., L. M. Corash, D. D. Davenport, J. Miraglia, and E. L. Amorosi. 1968. In vivo lability of glucose-6-phosphate dehydrogenase in GdA- and GdMediterranean deficiency. J. Clin. Invest. 47: 940.

24. Perutz, M. F., and H. Lehmann. 1968. Molecular pathology of human haemoglobin. Nature (London). 219: 902.

25. Dickerson, R. E., and L. Geis. 1969. The Structure and Action of Proteins. Harper \& Row, Publishers, New York. 67.

26. Feig, S. A., D. G. Nathan, and P. S. Gerald. 1970. Congenital methemoglobinemia with an unstable enzyme activity. Program of the American Society of Hematology 13th Annual Meeting. 143. (Abstr. 311.) 